\title{
KUALITAS PENYELENGGARAAN PENDIDIKAN AGAMA PADA PROGRAM PAKET A, B, DAN C
}

\author{
Farida Hanun \\ Puslitbang Pendidikan Agama dan Keagamaan | Balitbang dan Diklat Kemenag RI \\ Jl. MH Thamrin No.6 Jakarta Pusat | Email: farida_ridwan@yahoo.com
}

\begin{abstract}
This research is to identify: the progress of the religious educations' program towards the package A, B, and $C$ program that are spread to 7 provinces in Indonesia. Survey method appears as the method used in this research. The result of the research indicates: 1) the obligation for the people to attend the educational religious course is considered still not well implemented by the institutions' packages, 2) the amount of religious tutors in the establishment of religious education by the third package is still few, 3) religious tutors with irrelevant background to the formal education still exist 4) There are program organizers that are still considering the implementation of religious education appear not as a compulsory lesson, 5) the coordination between the ministry of religious affairs and the ministry of education and culture is still considered low related to the religious education's establishment on the package.
\end{abstract}

Keyword: quality, religious education, package.

\section{Abstrak}

Penelitian ini bertujuan untuk mengetahui: sejauhmana penyelengaraan pendidikan agama pada program paket di 385 Lembaga Program Paket A, B, dan C yang tersebar pada 7 propinsi di Indonesia. Metode yang digunakan adalah metode survei.Hasil penelitian menunjukkan:1) belum seluruhnya lembaga program paket mewajibkan warga belajar mengikuti mata pelajaran pendidikan agama, 2) jumlah tenaga tutor agama dalam penyelenggaraan pendidikan agama pada program paket3masih terbatas2) masih ada tutor agama yang belum sesuai dengan latar belakang pendidikan formal, 4) masih ada pengelola program paket yang menganggap keberadaan pelajaran pendidikan agama hanya sebagai pelajaran tambahan bukan pelajaran inti, 5) kerjasama Kementerian Agama dengan Kementerian Pendidikan dan Kebudayaan masih kurang terkait penyelenggaraan pendidikan agama pada program paket.

Keywords: Kualitas, Pendidikan Agama, program paket.

\section{PENDAHULUAN}

Agama memiliki peran yang amat penting dalam kehidupan umat manusia. Agama menjadi pemandu dalam upaya mewujudkan suatu kehidupan yang bermakna, damai dan bermartabat. Menyadari betapa pentingnya peran agama bagi kehidupan umat manusia maka internalisasi nilai-nilai agama dalam kehidupan setiap pribadi menjadi sebuah keniscayaan, yang ditempuh melalui pen- didikan baik pendidikan di lingkungan keluarga, sekolah maupun masyarakat. Internalisasi nilai-nilai agama di sekolah, menjadi sangat penting mendapat perhatian karena dapat mendorong peserta didik untuk taat menjalankan ajaran agamanya dalam kehidupan sehari-hari dan menjadikan agama sebagai landasan etika dan moral. Terkait dengan pentingnya pendidikan agama, Neil Postman menganjurkan untuk mengawali 
pengenalan agama di sekolah dasar dan memberi kesempatan pada peserta didik untuk mempelajari agama. ${ }^{1}$

Pemerintah telah memberikan perhatian tentang pentingnya pendidikan agama. Dalam PP no 55 tahun 2007, pasal 3 menjelaskan setiap satuan Pendidikan pada semua jalur, jenjang, dan jenis pendidikan wajib menyelenggarakan pendidikan agama. Legitimasi yuridis itu mengisyaratkan betapa pentingnya pendidikan agama.

Pemerintah melalui Kementerian Pendidikan dan Kebudayaan telah menyelenggarakan pendidikan nonformal dan informal. ${ }^{2}$ Salah satu bentuk pendidikan non formal adalah pendidikan kesetaraan yang mencakup program Paket A setara SD/MI, Paket B setara SMP/MTs, dan Paket C setara SMA/MA.

Sehubungan dengan hal tersebut, pemerintah perlu melakukan pengawasan dan pembinaan penyelenggaraan pendidikan agama pada program Paket A, B dan C. Mata pelajaran pendidikan agama sebagai salah satu mata pelajaran yang wajib diberikan mempunyai peranan sangat strategis dan signifikan dalam pembentukan moral, akhlak dan etika peserta didik. Di sisi lain UU no 20 tahun 2003 telah menempatkan Pendidikan non formal program Paket A, B dan C setara dengan pendidikan formal. Adanya kesetaraan tersebut, maka penyelenggaraan pendidikan agama pada program Paket dituntut mempunyai kualitas yang sama dengan pendidikan formal, minimal harus mampu memenuhi Standar Nasional Pendidikan (SNP).

Namun kenyataannya di lapangan, proses penyelenggaraan pendidikan agama banyak menemui berbagai kendala, sehingga ada beberapa penyelenggara pendidikan Kejar Paket yang tidak termotivasi untuk menyelenggarakan pendidikan agama. Misalnya PKBM Cengkareng Jakarta pimpinan

\footnotetext{
${ }^{1}$ Neil Postman. 2001. Matinya pendidikan:Redefinisi nilai-nilai sekolah. Yogyakarta: Jendela, h. 250

2 UU Nomor 20 Tahun 2003 tentang Sistem Pendidikan Nasional,Pasal 13 ayat 1.
}

Bapak Mulyadi. Mata pelajaran pendidikan agama di PKBM ini hanya diajarkan pada kelas 1 dan pada kelas selanjutnya tidak perlu diberikan sebagai mata pelajaran khusus, tapi cukup diintegrasikan saja ke dalam materi pengetahuan umum. ${ }^{3}$ Walaupun demikian ada juga beberapa penyelenggara kejar paket yang sudah menyelenggarakan pendidikan agama, misalnya PKBM Setia Mandiri Jakarta yang telah memasukkan materi pendidikan agama sebagai sebuah mata pelajaran khusus di setiap tingkatan kelas. ${ }^{4}$

Untuk melihat sejauhmana proses penyelenggaraan Pendidikan Agama pada program Paket A, Paket B, dan Paket C perlu adanya survei, Dengan alasan itu maka penelitian ini perlu dilakukan. Tulisan ini akan mengkaji: 1) apakah pendidikan agama sudah terselenggara pada program paket A, B dan C?, dan 2) faktor apa saja yang mendukung dan menghambat pelaksanaan pendidikan agama pada program paket A, B, dan C. Sementara manfaat studi ini diharapkan dapat memberikan data dan informasi pada Kementerian Agama sebagai bahan rujukan dalam menyusun rumusan dan pembinaan penyelenggaraan pendidikan agama pada program paket A, B, dan C dan pihak-pihak lain yang membutuhkan.

\section{Kerangka Teori}

\section{Program Pendidikan Kesetaraan Paket A, B,} dan C

Pendidikan Kesetaraan merupakan pendidikan nonformal yang mencakup program Paket A Setara SD/MI, Paket B Setara SMP/ MTs, dan Paket C Setara SMA/MA. ${ }^{5}$ Hasil pendidikan nonformal dapat dihargai setara dengan hasil

${ }^{3}$ Mulyadi. 2012. Makalah Pembelajaran Pendidikan Agama Islam Pada Warga Belajar Pendidikan Kesetaraan Paket A, Paket B, Paket C di PKBM Cengkarengi, Jakarta , h. 5

${ }^{4}$ Rosyidul Anam. 2012. Makalah: Proses Pembelajaran Pendidikan Agama Islam Pada Warga Belajar Pendidikan Kesetaraan Paket A, Paket B, Paket C di PKBM Setia Mandiri, Jakarta, h.. 12

${ }^{5}$ Direktorat Jenderal Pendidikan NonFormal dan Informal. 2007. Acuan Proses Pelaksanaan dan Pem- 
program pendidikan formal setelah melalui proses penilaian penyetaraan oleh lembaga yang ditunjukolehPemerintah atau pemerintah daerah dengan mengacu pada Standar Nasional Pendidikan. ${ }^{6} \quad$ Penyelenggaraan pendidikan kesetaraan Program Paket A, B dan C mulai tahun 2011 tidak lagi menjadi tugas Direktorat Jenderal Pendidikan Nonformal dan Informal, tetapi menjadi tugas Direktorat Pembinaan Sekolah Dasar dan Menengah sesuai dengan Permendiknas No. 36 Tahun 2010.

Sasaran Pendidikan Kesetaraan meliputi: Pertama, penduduk usia tiga tahun di atas usia SD/MI (13 - 15 th) untuk Paket A dan tiga tahun di atas usia SMP/MTs (16-18 tahun) untuk Paket B. Kedua, penduduk usia sekolah yang bergabung dalam komunitas e-/earning, sekolah rumah, dan sekolah alternatif, serta komunitas yang berpotensi khusus. Ketiga, penduduk usia sekolah yang terkendala ke jalur formal karena berbagai hal (faktor ekonomi, waktu, sosial dll). Keempat, penduduk usia 1544 yang belum tuntas wajib belajar pendidikan dasar 9 tahun. Kelima, penduduk usia SMA/ MA yang berminat mengikuti Program Paket C terutama karena masalah ekonomi. Keenam, penduduk di atas usia 18 tahun yang berminat mengikuti Program Paket C karena berbagai alasan.

Sebagai pendidikan berbasis masyarakat dan meluas, program Pendidikan Kesetaraan dapat diselenggarakan oleh berbagai bentuk lembaga, organisasi, dan komunitas belajar. Karakteristik Penyelenggara Komunitas Belajar sebagai berikut: PKBM (Pusat Kegiatan Belajar Masyarakat), SKB (Sanggar Kegiatan Belajar), Pondok Pesantren, Majlis Taklim, Sekolah rumah, Sekolah alam, Sekolah Kelas Campuran, Susteran, Diklat-diklat dan Unit Pelaksanan Teknis. ${ }^{7}$

belajaran Pendidikan Kesetaraan Program Paket A, B dan C, Departemen Pendidikan Nasional, h. 2-5

${ }^{6}$ Undang-undang Nomor 20 Tahun 2003 Tentang Sistem Pendidikan Nasional Pasal 26 Ayat 6.

${ }^{7}$ Op. cit., h. 14-17.

\section{Penyelenggraan Pendidikan Agama Di Program Kejar Paket A, B Dan C}

Pendidikan agama menurut Peraturan pemerintah No 55 Tahun 2007 Pasal 1 adalah pendidikan yang memberikan pengetahuan dan membentuk sikap, kepribadian dan ketrampilan peserta didik dalam mengamalkan ajaran agamanya, yang dilaksanakan sekurangkurangnya melalui mata pelajaran/kuliah pada semua jalur, jenjang dan jenis pendidikan.

Berkaitan dengan bentuk-bentuk penyelenggaraan pendidikan agama, Pemerintah telah menetapkan beberapa regulasi yang mendukung penerapan PAI di setiap satuan pendidikan. Undang-undang Nomor 20 Tahun 2003 Tentang sistem Pendidikan Nasional Pasal 12 ayat (1) berbunyi setiap peserta didik pada setiap satuan pendidikan berhak mendapatkan pendidikan agama sesuai dengan agama yang dianutnya dan diajarkan oleh pendidik yang seagama.

Sedangkan pasal 4 ayat (1) berbunyi: Pendidikan agama pada pendidikan formal dan program pendidikan kesetaraan sekurangkurangnya diselenggarakan dalam bentuk mata pelajaran atau mata kuliah agama dan ayat (2): Setiap peserta didik pada satuan pendidikan di semua jalur, jenjang, dan jenis pendidikan berhak mendapat pendidikan agama sesuai agama yang dianutnya dan diajar oleh pendidik yang seagama.

Undang-undang tersebut menunjukkan pendidikan agama sebagai salah satu mata pelajaran, wajib diselenggarakan pada setiap jalur, jenjang, dan jenis pendidikan. Oleh karena itu pemerintah termasuk pemerintah daerah harus secara sadar bertanggungjawab atas penyelenggaraan pendidikan agama khususnya di lembaga non formal.

Adapun komponen sistem pendidikan menurut Combs sebagaimana yang dikutip Fattah meliputi: tujuan dan prioritas, peserta didik, manajemen, struktur dan jadwal, Isi, guru, alat bantu belajar, fasilitas, teknologi, pengawasan mutu, penelitian dan biaya. ${ }^{8}$

8 Nanang Fattah. 1997. Landasan Manajemen Pendidikan. Bandung: PT Remaja Rosda Karya, h. 7. 
Selanjutnya khusus berkaitan kurikulum pendidikan agama Islam, maka guru agama diharapkan dapat menyelenggarakan pendidikan agama sesuai dengan standar isi, standar proses dan standar kompetensi lulusan pada program Kerja Paket A, B dan C.

Pertama, Standar Proses. Sesuai Permendiknas No 3 tahun 2008, Standar Proses adalah standar nasional pendidikan yang berkaitan dengan pelaksanaan pembelajaran pada satuan pendidikan untuk mencapai standar kompetensi lulusan. Standar proses pendidikan kesetaraan meliputi perencanaan, pelaksanaan, penilaian, hasil pembelajaran, dan pengawasan proses pembelajaran. Proses pembelajaran pendidikan kesetaraan dapat ditempuh melalui kegiatan tatap muka, tutorial, mandiri dan/atau kombinasi ketiganya.

Kedua, Standar Isi. Permendiknas No 14 tahun 2007 menjelaskan bahwa Standar Isi pembelajaran pendidikan agama untuk Program Paket A, B, dan C yang selanjutnya disebut standar isi mencakup lingkup materi minimal dan tingkat kompetensi minimal untuk mencapai kompetensi lulusan minimal pada program Paket A, B, dan C. Standar Isi yang dikembangkan oleh Badan Standar Nasional Pendidikan (BSNP) memuat: 1) kerangka dasar dan struktur kurikulum, 2) beban belajar, 3) kurikulum program Paket A, B, dan C, dan 4) kalender pendidikan. (Peraturan Pemerintah Nomor 19 Tahun 2005 tentang Standar Nasional Pendidikan).

Ketiga, Standar Kompetensi Lulusan. Sesuai Peraturan Menteri Pendidikan Nasional Nomor 14 Tahun 2007 tentang Standar lsi Kurikulum Program Pendidikan Kesetaraan Paket A, B dan $C$ ditegaskan bahwa tujuan pendidikan kesetaraan Paket A, B dan C harus memenuhi standar kompetensi lulusan yang sama dengan jenjang sekolah dasar dan menengah.

Dari uraian di atas, yang dimaksud dengan penyelenggaraan pendidikan agama dalam penelitian ini adalah kegiatan pelaksanaan pendidikan agama pada program kejar Paket A,
Paket $B$, dan Paket $C$ dengan tujuan membentuk sikap, kepribadian, dan keterampilan peserta didik dalam mengamalkan ajaran agamanya, yang dilaksanakan sekurang-kurangnya melalui mata pelajaran pada semua jalur, jenjang, dan jenis pendidikan.

\section{Metode Penelitian}

Penelitian ini dilakukan pada bulan MeiJuli tahun 2012 dengan menggunakan metode survei dengan teknik statistik deskriptif. Populasi target sebanyak 13829 lembaga paket yang berada di seluruh Indonesia Populasi terjangkaunya 7148 program paket. Dengan margin error $\pm 5 \%$ ditetapkan besaran sampel 385 lembaga melalui teknik pengambilan sampel multi stage random sampling." Sampel dialokasikan pada 6 propinsi $=$ Aceh, Kalimantan Barat, Sulawesi Selatan, Jawa Barat, Jawa Tengah, dan NTB. Sampel diambil menurut proporsi masing-masing propinsi pada program paket A, B dan C secara cluster. Kemudian setiap program paket di propinsi, sampel dipilih menurut proporsi kabupaten terbanyak. Selanjutnya di masing-masing kabupaten terpilih, sampel dipilih secara acak.

Adapun pengumpulan data dilakukan dengan menggunakan beberapa teknik: kuesioner; studi kepustakaan, wawancara. Data kuantitatif yang terkumpul dari kuesioner dideskripsikan menggunakan tabel dan grafik. Untuk lebih memperdalam analisis data kuantitatif juga digunakan data kualitatif hasil wawancara dan studi kepustakaan.

\section{HASIL DAN PEMBAHASAN}

\section{Penyelenggaraan Pendidikan Agama}

Pembelajaran pendidikan agama wajib diselenggarakan oleh semua satuan pendidikan baik di lembaga formal maupun nonformal. Namun kenyataannya dari grafik diketahui

${ }^{9}$ Djaali. 2003. Bahan Ajar Metode Penelitian. Jakarta: PPs UNJ, h. 78-79. 
bahwa dari 385 lembaga yang disurvei, sebanyak $318(82,60 \%)$ telah menyelenggarakan pendidikan agama dan hanya 67 lembaga $(17,40 \%)$ yang tidak menyelenggrakan pendidikan agama. Artinya belum semua program paket yang merasa perlu warga belajarnya mendapatkan pendidikan agama.

Grafik 1:

Keberadaan Pendidikan Agama Pada Program Paket

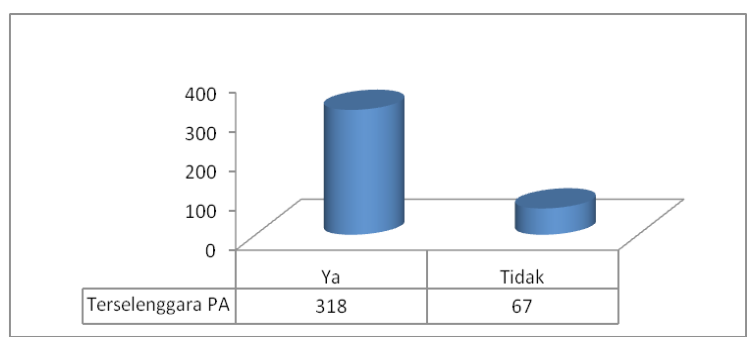

Berkaitan dengan Lembaga-lembaga program paket yang menyelenggarakan penddikan agama (PA), hasil survei dari 318 lembaga terdapat lembaga Pusat Kegiatan Belajar Masyarakat (PKBM) sebanyak 258 lembaga (81,13\%), Yayasan 44 lembaga (13,84\%), Lembaga Swadaya Masyarakat (LSM) sebanyak 5 lembaga (1,57\%), Unit Pelaksana Teknis (UPDT) 4 lembaga (1,26\%), Lainnya 7 lembaga $(2,2 \%)$. Data menunjukkan pengelola program paket paling banyak menyelenggarakan PA dilakukan oleh PKBM

Grafik 2: Lembaga penyelenggara PA

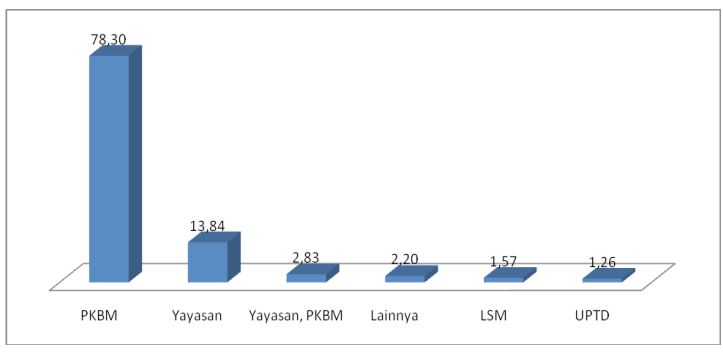

PKBM merupakan institusi pendidikan nonformal yang dimiliki dan dikelola oleh masyarakat atau ormas, orsosmas atau organisasi keagamaan. Pemerintah berperan sebagai fasilitator. PKBM didirikan untuk pemberdayaan masyarakat; dalam aspek ekonomi, budaya, pendidikan, sosial dan sekaligus merupakan tempat atau pusat belajar masyarakat; oleh, dari dan untuk masyarakat yang netral dan fleksibel.

\section{Peta Permasalahan}

Masih ada tutor yang belum memenuhi kompetensi standar tutor

Dalam sebuah lembaga pendidikan, salah satu faktor terpenting berhasilnya proses pembelajaran PA di kelas adalah kompetensi Tutor PA. Tugas tutor PA bukanlah mengajar tetapi membimbing warga belajar dalam memahami materi pelajaran agama, sehingga proses pembelajarannya dapat berjalan dengan lancar.

Untuk dapat membuat program pengajaran pendidikan agama, seorang tutor PA harus mempunyai beberapa kemampuan: a) mengidentifikasi kebutuhan belajar, b) menyusun program pembelajaran PA yang berorientasi pada tujuan yang diinginkan warga belajar, c) berkomunikasi agar mampu menggunakan berbagai cara alam pembelajaran, d) menjalankan program dalam arti kemampuan mengorganisir program, e) menilai hasil program, dan f) menggunakan hasil penilaian dalam usaha memperbaiki program di masa mendatang.

Kemampuan-kemampuan mengajar di atas hanya akan diperoleh dari tutor yang mempunyai latar belakang pendidikan agama sehingga akan memiliki kompetensi pedagogik, personal, professional dan sosial serta didukung dengan kualifikasi pendidik yang sesuai. ${ }^{10}$

Namun di lapangan masih ada beberapa penyelenggara program paket yang memiliki tutor PA tidak sesuai dengan latar belakang

${ }^{10}$ Direktorat Jenderal Pendidikan NonFormal dan Informal. 2007. Acuan Proses Pelaksanaan dan Pembelajaran Pendidikan Kesetaraan Program Paket A, B dan C, Departemen Pendidikan Nasional, h. 23-30. 
pendidikan formal. Hasil penelitian ini menunjukkan dari 296 lembaga kejar paket yang dikelola swasta, terdapat sejumlah 224 lembaga $(75,7 \%)$ yang memiliki tutor sesuai dengan pendidikan formal dan sisanya 72 $(24,3 \%)$ tidak sesuai.

Sedangkan program paket yang dikelola pemerintah, terdapat sejumlah 18 lembaga $(81,8 \%)$ yang mempunyai kesesuaian latar belakang pendidikan dan 4 lembaga $(18,2 \%)$ tidak sesuai. Dari uraian di atas, disimpulkan program paket baik yang dikelola oleh swasta atau pemerintah, masih ada tutor agama yang belum sesuai dengan latar belakang pendidikan. Padahal kesesuaian latar belakang pendidikan formal tutor akan berkorelasi dengan keberhasilan mengajar pendidikan agama.

Melihat kondisi ini, pihak swasta dan pemerintah harus mencari jalan keluar dengan melakukan kerja sama antara pimpinan lembaga kejar paket dengan Kementerian Pendidikan dan Kebudayaan serta Kementerian Agama untuk menyediakan tutor pendidikan agama yang berlatar belakang pendidikan formal pendidikan agama.

Masih banyak Lembaga program paket yang belum mempunyai rumah ibadah.

Selain sebagai tempat ibadah. Selain Mesjid juga merupakan sarana pendidikan Islam di sekolah di antaranya sebagai pusat kegiatan-kegiatan perayaan hari besar, diskusi, kajian agama, ceramah, praktek pendidikan agama Islam dan belajar Al Qur'an. Demikian besarnya manfaat keberadaan masjid, namun masih banyak lembaga pendidikan program paket yang tidak mempunyai rumah ibadah.

Dari 385 lembaga, yang menyelenggarakan pendidikan agama $318(82,60 \%)$ dan hanya 67 lembaga $(17,40 \%)$ tidak menyelenggarakan pendidikan agama. Selanjuynya dari 67 tersebut, ternyata 54 lembaga $(80,60 \%)$ tidak memiliki rumah ibadah. Data ini menunjukkan sebagian besar lembaga yang tidak menyelenggarakan PA tidak memiliki rumah ibadah. Padahal keberadaan rumah ibadah sangat mendukung terselenggaranya pembelajaran pendidikan agama.

Belum seluruh Lembaga program paket mewajibkan warga belajar mengikuti mata pelajaran pendidikan agama

Angka putus sekolah dan angka melanjutkan ke jenjang pendidikan yang lebih tinggi merupakan gambaran dari jumlah sasaran peserta didik. Dari data di atas terlihat bahwa 67 lembaga yang tidak menyelenggarakan pendidikan agama, terdapat 2126 warga belajar, dengan rincian yang berusia < 12 tahun sebanyak 21 orang (1\%), berusia 13-15 tahun sebanyak 172 orang (8\%), berusia 1618 th sebayak 922 orang (43\%), dan di atas 19 tahun sebanyak 1001 orang (47\%). Sedikitnya warga belajar < 12 tahun dikarenakan pada usia tersebut peserta didik sudah masuk ke sasaran progran SD/SMP satu atap dan SMP terbuka.

Selanjutnya data di atas juga menunjukan warga belajar berusia 16 sd 18 tahun yang berada pada paket B dan C banyak yang tidak mengikuti pelajaran PA dengan berbagai alasan di antaranya: latar belakang sosial ekonomi warga belajar lemah dan dengan frekuensi kehadirannya yang rendah karena disibukkan untuk mencari nafkah keluarga, sehingga motivasi untuk belajar agama tidak begitu tinggi, dan mereka merasa tanpa diajarkan pendidikan agama mereka sudah tahu (sudah belajar agama sebelum umur 16 tahun).

Hasil penelitian membuktikan alasan mengapa siswa tidak mengikuti pelajaran pendidikan agama. Dari 92 lembaga yang telah menyelenggarakan pendidikan agama tetapi tidak mewajibkan semua siswa untuk mengikuti pelajaran agama dengan alasan: sibuk kerja dan sudah mengetahui dasar-dasar agama sebanyak 26 orang $(28,26 \%)$, sibuk kerja 24 orang (26\%), tidak ada waktu 22 orang $(23,91 \%)$, sibuk kerja dan tidak ada waktu sebanyak 12 orang $(13,04 \%)$, sudah mengetahui dasar-dasar agama sebanyak 7 orang (7,61\%), sedangkan yang menjawab alasan tidak ada 
waktu dan sudah mengetahui dasar-dasar agama hanya 1 orang $(1,09 \%)$.

Data di atas menunjukkan sebagian besar siswa yang tidak mengikuti pembelajaran pendidikan agama memberikan alasan sibuk kerja dan sudah mengetahui dasar-dasar agama. Dengan kondisi warga belajar seperti ini berdampak pada beberapa lembaga program kejar paket ada yang tidak mewajibkan warga belajar mengikuti mata pelajaran pendidikan agama di lembaga pendidikan tersebut.

Masih banyak pengelola program paket menganggap pelajaran pendidikan agama (PA) hanya sebagai pelajaran tambahan

Selama ini mata pelajaran yang diuji nasionalkan pada beberapa program paket adalah mata pelajaran umum. Misalnya program paket $C$ jurusan IPS adalah mata pelajaran Matematika, Bahasa Indonesia, Bahasa inggris, Sosiologi dan Tatanegara, sedangkan jurusan IPA adalah mata pelajaran Matematika, Bahasa Indonesia, Bahasa Inggris, Fisika, Kimia dan Biologi.

Adapun untuk mata pelajaran pendidikan agama tidak termasuk mata pelajaran yang di UN kan, sehingga selama ini ada kesan bahwa pendidikan agama hanyalah mata pelajaran tambahan (supplement) dan bukan sebagai mata pelajaran inti), karena tidak masuk dalam Ujian Nasional (UN).

Kondisi ini berdampak adanya sebagian lembaga paket tidak menyelenggarakan pendidikan agama dengan berbagai alasan. Sesuai dengan hasil survei dari 41 lembaga berkaitan dengan alasan mengapa beberapa lembaga program paket tidak menyelenggarakan PA, menunjukkan alasan sebagai berikut: Pendidikan agama tidak masuk pelajaran yang di UN-kan tidak ada dana untuk membiayai pembelajaran pendidikan agama sebanyak 9 lembaga (21,95\%), pendidikan agama tidak masuk pelajaran yang di UN-kan sebanyak 7 lembaga $(17,07 \%)$, tidak ada dana untuk membiayai pembelajaran pendidikan agama sebanyak 7 lembaga $(17,07 \%)$, warga belajar telah mempunyai pengetahuan yang memenuhi persyaratan sebanyak 4 lembaga (9,76\%), sebab lainnya sebanyak 14 lembaga (34,15\%).

Data ini memperlihatkan bahwa alasan terbanyak kenapa PA tidak terselenggara adalah Pendidikan agama tidak masuk pelajaran yang di Ujian Nasional-kan dan tidak ada dana untuk membiayai pembelajaran pendidikan agama.

Masih ada lembaga program paket yang tidak menyelenggarakan PA karena keterbatasan tenaga tutor

Ada beberapa lembaga program paket yang tidak menyelenggarakan pendidikan agama dalam bentuk mata pelajaran dengan alasan tidak ada tutor. Dari beberapa jawaban yang diberikan oleh 13 lembaga, hasil survei menunjukkan penyebab kenapa tidak ada tutor PA karena: tidak ada alokasi anggaran untuk biaya tutor PA sebanyak 21 lembaga (51,22\%), tidak bersedia menjadi tutor, karena kecilnya honor sebanyak 7 lembaga $(17,07 \%)$, tidak bersedia menjadi tutor, karena kecilnya honor dan tidak ada alokasi anggaran tutor PA sebanyak 3 lembaga (7,32\%), sulit mendapatkan tutor yang mau mengajar PA sebanyak 2 lembaga (4,88\%), Alasan lainnya ada 8 lembaga (19,51\%). Data ini menunjukkan bahwa penyebab terbesar alasan tidak adanya tutor adalah karena lembaga tidak ada alokasi anggaran untuk membiayai tutor PA.

Masih kurangnya kerjasama Kementerian Agama (Kemenag) dengan Kementerian Pendidikan dan Kebudayaan (Kemendikbud) pada beberapa lembaga program paket.

Dari 319 lembaga program paket yang pernah melakukan kerja sama dengan Kemenag maupun Kemendikbud sebanyak 36 lembaga $(11,32 \%)$ dan yang belum pernah 282 lembaga (88,68\%). Kondisi ini menunjukkan bahwa lebih banyak lembaga kejar paket yang belum pernah melakukan kerjasama antara Kemenag dengan Kemendikbud di lembaganya. 


\section{Peta Potensi}

Animo masyarakat lebih menginginkan penyelenggaraan pendidikan program paket $A, B$ dan $C$ dilengkapi dengan pendidikan agama (PA).

Penyelenggaraan pendidikan agama pada program paket sangat diperlukan supaya warga belajar mengenal,memahami, dan menjalankan ajaran agama. Agar situasi keagamaan yang kondusif bisa tercipta, maka perlu dirumuskan suatu strategi penyelenggaraan pendidikan agama di lembaga paket yang tepat sehingga dapat mensiasati keterbatasan jam pelajaran yang hanya dua jam pelajaran saja sementara materi yang harus disampaikan begitu banyak dan harus menyentuh seluruh aspek, baik aspek kognitif, afektif maupun psikomotor.

Dengan waktu pembelajaran pendidikan agama yang hanya minimal 2 jam, saat ini sudah ada beberapa lembaga paket yang menyelenggarakan pendidikan agama. Dari 385 lembaga program paket yang disurvei, ada 318 yang menyelenggarakan PA dan tersebar di program paket A sebanyak 57 lembaga (17,9\%), Paket B sebanyak 151 lembaga $(47,74 \%)$ dan Paket C sebanayak 110 lembaga (34,6\%). Data ini memperlihatkan ketersebaran lembaga program paket yang menyelenggarakan pendidikan agama paling banyak teradapat di lembaga program paket B dan paling sedikit di Paket A. Kondisi ini berhubungan juga dengan makin sedikitnya pengelola program paket yang menyelenggaraka program paket A.

Selanjutnya jika dilihat dari komposisi masing-masing propinsi, maka jumlah lembaga program paket yang telah menyelenggarakan pendidikan agama di 7 propinsi di antaranya: Aceh 22 (6,9\%), Jawa Barat 50 (15,7\%), Jawa Tengah 64 (20,1\%), Jawa Timur 81 (25,5\%), Kalimantan Barat 23 (13,5\%), NTB 43 (13,5\%), Sulsel 35 (11\%) lembaga. Data memperlihatkan bahwa penyelenggaraan pendidikan agama pada program paket terbanyak ada di propinsi Jawa Timur, diikuti propinsi Jawa Tengah, Jawa Barat dan Nusa Tenggara Barat. Kondisi ini tidak terlepas dari dukungan masyarakat di keempat propinsi tersebut, karena pendidikan pada dasarnya selalu memiliki hubungan timbal balik dengan sistem masyarakat yang ada di luarnya. Oleh karena itu jika pengelola kejar paket pandai menangkap keinginan masyakat yang lebih menginginkan penyelenggaraan pendidikan dilengkapi dengan pendidikan agama, maka kemungkinan lembaga kejar paket tersebut akan banyak diminati masyarakat.

Sebagian Besar Pendidikan Program Paket Sudah Menggunakan Kurikulum KTSP.

Dalam penyelenggaraan pendidikan agama di sebuah lembaga formal atau non formal diperlukan sebuah kurikulum sebagai panduan atau pedoman, begitu pula yang terjadi di lembaga program paket. Dari 318 lembaga, kurikulum PA yang digunakan di antaranya: KTSP sebanyak 219 lembaga $(68,87 \%)$, Kurikulum dari yayasan sebanyak 48 lembaga (15,09\%), KBK sebanyak 24 lembaga (7,55\%), dan yang menggunakan KTSP plus kurikulum yayasan sebanyak 12 lembaga (4,72\%), lainnya 15 lembaga (4,72\%). Hasil survel ini menunjukkan sebagaian besar lembaga paket menggunakan kurikulum KTSP. Kondisi ini sangat mendukung terlaksananya penyelengaraan pendidikan agama yang maksimal dan akan memudahkan pengelola pendidikan program paket untuk menyelenggarakan pendidikan agama yang sesuai dengan standar kurikulum nasional.

Munculnya Ragam Pola Penyelenggaraan PA di Lembaga Program Paket

Untuk keterkaitan antara pola pelaksanaan jadwal pelajaran PA yang dilakukan oleh pihak swasta dan pemerintah dapat di lihat sebagai berikut:

Data menunjukkan bahwa bentuk pembelajaran yang dikelola swasta dengan pemerintah agak berbeda. Dari 215 lembaga yang dikelola pihak swasta, sebanyak 195 lembaga menggunakan bentuk berjenjang (pengelolaan sistem belajar menggunakan bentuk klasikal atau berkelas) dan yang tidak berjenjang (sistem pembelajaran per tahun ajaran dalam bentuk 
rombongan dan tidak berkelas) ada 20 lembaga. Sebaliknya program paket yang dikelola pemerintah $100 \%$ berbentuk berjenjang. Hal ini menunjukkan program paket lebih banyak yang menggunakan bentuk berkelas karena berkaitan dengan tingginya motivasi warga belajar yang masuk ke program paket yang menggunakan pembelajaran sistem klasikal, warga belajar mengharapkan adanya proses pembelajaran pendidikan agama yang lebih rapih dan berjenjang/klasikal

Berkaitan dengan pola pelaksanaan kurikulum (ekstra dan intra), khusus yang dikelola oleh swasta yang berbentuk berjenjang/ kelas, sebanyak 195 lembaga dimasukan ke ekstra kurikuler (45) lembaga, dimasukkan ke kurikulumdanekstrakurikuler(14),terintegrasi (4) lembaga. Sedangkan yang berbetuk tidak berjenjang: dimasukkan dalam kurikulum ada 20 lembaga, dimasukan ke ekstra kurikuler (13), dimasukkan ke kurikulum dan ekstra kurikuler (3), terintegrasi (1) lembaga. Adapun penyelenggaraan PA yang dikelola pihak pemerintah pengelolaanya menggunakan pola: dimasukkan dalam kurikulum sebanyak 16 lembaga, dimasukan ke ekstra kurikuler (3), dimasukkan ke kurikulum dan ekstra kurikuler (3), terintegrasi (0) lembaga.

Dari pola pengaturan jadwal pelajaran PA, hasil penelitian menunjukkan bahwa penyelengggaraan PA baik yang dikelola oleh swasta maupun pemerintah, sebagian besar polanya dalam bentuk mata pelajaran yang dimasukkan didalamjadwal kurikulum. Artinya penyelenggaraan pendidikan agama sudah dalam bentuk sebuah mata pelajarn khusus dan terjadwal dalam kurikulum sekolah, sesuai dengan standar proses pembelajaran program paket. ${ }^{11}$ Hal ini menunjukkan keseriusan sebagan besar pihak pengelola lembaga program paket untuk menyelenggarakan pendidikan agama di lembaga pendidikan program kejar paket. 2008.

\footnotetext{
${ }^{11}$ Peraturan Mentri Pendidikan Nasional No 3 tahun
}

Munculnya ragam pola penyelenggaraan PA di lembaga program Paket merupakan peluang untuk mencari model pembelajaran PA yang sesuai dengan kondisi warga belajar di pendidikan program paket.

Banyaknya tutor PA yang direkrut sebagai guru PA berstatus PNS yang kekurangan jam

Bagi penyelenggaraa program paket yang telah melaksanakan pembelajaran pendidikan agama, ada beberapa faktor pendukung yang mempermudah terlaksananya pembelajaran Pendidikan Agama, yaitu banyaknya tutor PA yang berstatus PNS yang kekurangan jam

Hasil penelitian menunjukkan ada beberapa faktor pendukung terlaksananya pembelajaran PA. Dari 318 lembaga, faktor pendukung terselenggaranya PA di antaranya: 1) Dana, jaringan, dan tutor PA yang berstatus PNS banyak kekurangan jam sebanyak $19,8 \%$, 2) Sarana dan dana sebanyak $11,3 \%, 3)$ Kepemimpinan sebanyak 5,3\%, 4) Kepemimpinan dan Kompetensi tutor PA sebanyak 3,8\%, 5) Kepemimpinan, sarana, dan kompetensi Tutor PA sebanyak 3,5\%, 6) Sarana, dana danjaringan dengan instansilain sebanyak $3,1 \%, 7)$ Kompetensi tutor PA sebanyak 3,1\%, dan 8) faktor lainnya $24,5 \%$. Dapat diambil kesimpulan berdasarkan hasil penelitian di atas bahwa tutor PA yang berstatus PNS yang kekurangan jam merupakan salah satu faktor pendukung ketersediaan turor PA di lembaga program Paket.

Berkaitan dengan banyaknya Guru PNS yang berdinas di suatu sekolah dan dia menambah jamnya di luar sekolah tempat berdinas misalnya mengajar PAI pada kejar paket hal ini di perbolehkan, dengan landasan yuridis pasal 52 ayat (2) Peraturan Pemerintah Nomor 74 tahun 2008 tentang guru dan pasal 1 Peraturan Menteri Pendidikan Nasional Nomor 39 Tahun 2009 tentang Pemenuhan Beban Kerja Guru dan Pengawas Satuan Pendidikan. Kedua landasan itu mengamanatkan bahwa beban kerja guru paling sedikit 24 jam tatap muka. 
Selanjutnya dalam Pedoman Pelaksanaan Pemenuhan Beban Kerja PAI pada Sekolah yang diterbitkan oleh Direktorat Pendidikan Agama Islam Kementerian Agama menjelaskan: dalam rangka pemenuhan beban kerja guru PAI, maka bagi guru PAI pada satuan pendidikan yang tidak dapat memenuhi beban kerja mengajar minimal 24 jam tatap muka dalam 1 minggu dapat memilih alternatif kegiatan di antaranya: menjadi tutor program paket A, B, C atau Paket $C$ kejuruan dan dapat diperhitungkan sebagai alternatif pemenuhan beban kerja, dengan ketentuan sebagai berikut: 1) status sebagai tutor program Paket A, B, C atau Paket C Kejuruan, diterbitkan melalui SK Kepala Kantor Kemenag Kab/Kota, 2) mata pelajaran yang ditutorialkan oleh guru PAI harus sesuai dengan sertifikat pendidiknya, 3) SK Kepala Kantor Kemenag sebagaimana dimaksudkan huruf (a) di atas, dibuat sesuai ketentuan yang berlaku dan harus menjelaskan tentang jadual, waktu dan tugas guru PAI yang bersangkutan dalam melakukan tutorial. ${ }^{12}$

Dari uraian diatas terlihat bahwa bagi guru pendidikan agama Islam dalam rangka memenuhi beban kerja guru mengajar paling sedikit 24 jam tatap muka, boleh memenuhi sebagian beban kerja mengajar sebagai tutor progran paket A, B dan C.

\section{Terbentuknya Jaringan Mitra penyelenggara PA}

Dalam menyelenggarakan pendidikan agama pada program paket, beberapa lembaga sudah melakukan hubungan kerjasama dengan beberapa pihak dalam bentuk jaringan mitra penyelenggaraan PA.

Pihak-pihak yang menjadi mitra penyelenggaraan PA di antaranya: Tokoh Agama $(64,03 \$)$, Lembaga Dakwah Lingkungan Setempat (7,91\%), Karang Taruna $(0,72 \%)$, mitra lainnya sebanyak (9,35\%), dan sebanyak $18,71 \%$ memilki dua mitra, sedangkan yang

12 Direktorat Pendidikan Agama Islam. 2011. Pedoman Pelaksanaan Pemenuhan Beban Kerja PAI pada Sekolah. Jakarta: Direktorat Jenderal Pendidikan Islam Kementerian Agama RI, h. 21. memilki tiga mitra hanya $0,72 \%$. Penelitian menunjukkan bahwa bentuk jaringan mitra penyelenggaraan PA terbanyak adalah bermitra dengan tokoh agama.

\section{Pengembangan Model Penyelenggaraan Pendidikan Agama}

Melihat hasil survei di atas, perlu kiranya pihak lembaga program paket memberi perhatian lebih terhadap PA. Pendidikan agama pada program paket yang diwujudkan dalam mata pelajaran pendidikan agama bertujuan sebagai upaya menyiapkan peserta didik untuk mengenal, memahami, menghayati hingga mengimani ajaran agama dibarengi dengan tuntunan untuk menghormati penganut agama lain dalam hubungannya dengan kerukunan antar umat beragama hingga terwujud kesatuan dan persatuan bangsa.

Pendidikan agama merupakan salah satu cara untuk menyentuh tiga komponen sikap keagamaan yang ada dalam diri manusia. Pertama komponen kognisi, adalah segala hal yang berhubungan dengan gejala fikiran seperti keimanan. Kedua, komponen afeksi, adalah segala hal yang berhubungan dengan gejala perasaan (emosional: seperti senang, tidak senang, setuju). Ketiga, komponen konasi yaitu kecenderungan untuk berbuat, seperti memberi pertolongan, menjauhkan diri dan mengabdi. Pengembangan potensi keagamaan tersebut akan mampu memperbaiki akhlak dan mendidik hati nurani dan mendorong mereka untuk memperbuat pekerjaan yang mulia. Dengan pendidikan agama, maka waga belajar menjadi tahu dan mengerti akan kewajibannya sebagai umat beragama

Di sisi lain pemerintah sebagai instansi yang menyelenggarakan program paket perlu memberikan perhatian serius dalam penyelenggaraan pendidikan agama. Perhatian itu dapat diwujudkan dengan merumuskan dan menetapkan bebarapa aturan (regulasi) yang mendukung penerapan PA, sehingga lembaga program paket dapat bernuansa 
agamis, bukan saja dalam bentuk formal, akan tetapi terjadinya proses penanaman nilai-nilai keberagamaan dalam perilaku dan kepribadian peserta didik.

Kedepan pemerintah perlu membuat beberapa desain pengembangan penyelenggaraan pendidikan agama di lembaga program paket, di antaranya sebagai berikut:

\section{Modul Pendidikan Agama}

Hasil penelitian menunjukkan berkaitan dengan buku/modul pembelajaran pendidikan agama menunjukkan dari 318 lembaga ada 158 lembaga (49,69\%) yang mempunyai buku pedoman untuk warga belajar, namun sisanya 160 lembaga $(50,31 \%$ ) belum mempunyai buku.

Selanjutnya bagi lembaga yang sudah mempunyai buku/modul PA, hasil survei memperlihatkan sumber buku pedoman PA berasal dari: Yayasan $37,11 \%$, Perpustakaan 24,53\%, Sumbangan dari Kemenag 9,43\%, Tutor PA membuat sendiri modul pembelajaran PA $7,55 \%$, Warga belajar membeli sendiri 5,66\%, asal buku lainnya 9,43\%, dan sebanyak 6,29\% mempunyai dua asal buku.

Bervariasinya sumber buku/modul PA, di antaranya ada yang dibelikan oleh yayasan, ada yang membuat sendiri, membeli sendiri, ada juga beberapa lembaga yang mendapatkan sumbangan buku PA dari Kemenag. Melihat kondisi ini maka program pengembangan ke depan mengatasi lembaga yang belum memiliki buku/modul pendidikan agama, maka pemerintah perlu mensosialisasikan dan mendistribusikan sekaligus memperbanyak buku/modul agama.

\section{Rekrutmen Tutor}

Bagi lembaga-lembaga yang sudah menyadari akan pentingnya pendidikan agama tapi belum menyelenggarakan pendidikan agama karena banyaknya kendala yang harus di hadapi, di antaranya keterbatasan tenaga tutor. Namun mereka menyadari bahwa bagaimanapun juga mata pelajaran PA sangat penting untuk warga belajar oleh karena itu segala rintangan yang menghambat terselenggaranya pendidikan agama harus di cari jalan keluarnya. Ke depan jika akan menyelenggarakan pendidikan agama, mereka akan mencoba merekruitmen tenaga tutor dari berbagai sumber.

Dari hasil survei di 318 lembaga berkaitan dengan bagaimana cara mengatasi ketersediaan tutor PA, rencana rekruitmen tenaga tutor memberdayakan tutor mata pelajaran lain untuk mengajar pendidikan agama 52 (16,35\%), adanya tenaga sosial/warga masyarakat yang menawarkan diri untuk menjadi tutor 47 (14,78\%), tes seleksi 3,46\%, adanya rekomendasi dari Kementrian Agama $\mathrm{Kab} /$ Kota $0,94 \%$, meminta kepada tutor pada pesantren terdekat 0,94\%, dan lainnya 13, 49\%

Kementerian Agama dan Kementerian Pendidikan dan Kebudayaan sebagai wadah yang ikut membina tutor penyelenggaraan PA sebaiknya merekrut tutor yang akan mengajar di program paket dari berbagai kalangan di antaranya pesantren, ormas, sekolah/ madrasah terdekat atau meminta ke Dinas Pendidikan.

\section{Kompetensi Tutor}

Berkaitan dengan kompetensi tutor, hasil penelitian menunjukkan ada guru yang belum sesuai dengan latar belakang pendidikan. Dari hasil suvei di 318 lembaga, masih ada 76 lembaga $(23,90 \%)$ yang tidak sesuai latar belakang pendidikan, artinya ada juga yang belum memiliki kompetensi PA.

Bagi lembaga yang belum memiliki tutor yang berkompeten, ke depan perlu di cari cara menyediakan tutor agama yang berkompeten untuk dipekerjakan di program paket. Model penyediaan tutor PA yang kompeten bisa diambil dari tutor PA yang berstatus PNS yang kekurangan jam atau para penyuluh agama (PNS) yang ada di kementerian agama. Oleh karena itu Pemerintah (kementerina agama bekerja sama dengan Kementerian Pendidikan dan Kebudayaan) perlu membuat model 
penyediaan tutor PA yang kompetensi sesuai standar pengelolaan pendidikan.

\section{Supervisi}

Penyelenggaraan pendidikan agama selama ini hanya di supervisi oleh pimpinan lembaga. Adapun peranan pengawas dari Kementerian Agama masih sedikit. Hal ini dapat di lihat dari hasil suvei yang menunjukkan dari 115 lembaga, pihak yang melakukan supervisi di antaranya: Pimpinan Lembaga 85 lembaga (73,91\%), Pengawas dari Kemenag 14 lembaga (12,17\%), Pimpinan Lembaga dan pengawas dari Kemenag 7 lembaga (6,09\%), Kementrian Pendidikan dan Kebudayaan 4 lembaga (3,48\%), pihak lainnya 5 lembaga (4,35\%).

Upaya mengatasi minimnya pelaksanaan supervisi, ke depan pihak Kementerian Agama melakukan kerja sama yang lebih baik lagi untuk melakukan supervisi yang lebih optimal dalam pengawasan pembelajaran pendidikan agama dan perlu dipikirkan bagaimana model supervisi yang efektif dalam pembinaan PA di lembaga kejar paket. Penting buat pemerintah untuk membuat kebijakan yang mempunyai daya ubah dalam memaksimalkan kegiatan supervisi dan ini belum maksimal di lakukan oleh pemerintah.

\section{Honor Tutor}

Berkaitan dengan pemberian honor kepada tutor PA, hasil survei menunjukkan Dari 318 lembaga, sumber anggaran dana program paket berasal dari: APBD/APBN $49,69 \%$, Yayasan 13,84\%, Iuran rutin warga belajar $24(7,55 \%)$, sumber anggaran lainya Lainnya 3,46\%. Sebanyak 22,01\% mempunyai dua sumber anggaran, dan sebanyak 0,94\% mempunyai tiga sumber anggaran.

Hasil wawancara dengan pihak pengelola program paket terungkap, bahwa walaupun sudah ada beberapa Pemerintah Daerah yang mendukung terselenggaranya pendidikan agama melalui pemberian honor kepada para tutor pendidikan agama, namun besarnya honor yang diberikan belum mencukupi. Ke depan pemerintah (PEMDA dan KEMENAG), perlu meningatkan pemberian insentif/honor bagi tutor PA yang lebih maksimal.

\section{Kerjasama Kemenag dengan Kemendikbud}

Ada beberapa lembaga yang sudah melakukan kerjasama dengan Kemenag atau Kemendikbud. Dari 36 lembaga, bentuk kerja sama yang dilakukan dalam bentuk Diklat tutor PA 19 lembaga (52,78\%), Modul Pelajaran PA 12 lembaga (33,33\%), MGMP PA bersama 1 lembaga (2,78\%), bentuk lainnya hanya 4 lembaga (11,11\%). Penelitian menunjukkan bahwa bentuk kerjasama dengan Kemenag atau Kemendikbud terbanyak dalam bentuk kerja sama diklat tutor PA.

Hasil penelitian menunjukkan telah ada kerjasama antara Kementerian Agama dan Kementerian Pendidikan dan Kebudayaan dalam berbagai bentuk. Namun ke depan diharapkan pemerintah lebih serius membuat model-model pengembangan pengelolaan penyelenggraaan PA di kejar paket, di antaranya:

Pertama, membuat model pengembangan diklat PA untuk lembaga kejar paket yang efektif dan maksimal hasilnya. Dengan adanya model pengembangan diklat PA, diharapkan dapat meningkatkan kemampuan tutor dalam proses belajar mengajar PA .

Kedua, membuat model penyelenggaraan MGMP Pendidikan Agama yang disesuaikan dengan kondisi pengelolaan Lembaga program paket. MGMP pendidikan agama adalah forum Madrasah Guru Mata Pelajaran Pendidikan Agama. Mengingat pentingnya penyelenggaraan MGMP Pendidikan Agama maka diharapkan ke depan pemerintah khususnya Kemenag dan Kemendikbud untuk membantu membuat model penyelenggaraan MGMP Pendidikan Agama yang efektif dan membuat desain anggaran untuk operasional kegiatan MGMP pendidikan agama. 


\section{PENUTUP}

\section{Kesimpulan}

1. Hasil survei, dari 385 lembaga, terdapat 318 program paket $(82,60 \%)$ yang menyelenggarakan pendidikan agama dan sisanya 67 lembaga (17,40\%) tidak menyelenggrakan pendidikan agama. Hal ini menunjukkan belum semua program paket merasa perlu warga belajarnya mendapatkan pendidikan agama

2. Penyelenggaraan pendidikan agama pada program paket ditemui beberapa kendala di antaranya: a) belum seluruhnya lembaga program paket mewajibkan warga belajar mengikuti pelajaran pendidikan agama, b) masih ada tutor yang belum memenuhi kesesuai latar belakang pendidikan formal, c) masih ada beberapa pengelola program paket yang menganggap keberadaan mata pelajaran pendidikan agama hanya sebagai pelajaran tambahan bukan mata pelajaran inti yang di ujian nasionalkan, d) terbatasnya jumlah tenaga tutor agama dalam penyelenggaraan pendidikan agama pada program paket, dan e) masih kurangnya kerjasama Kemenag dengan Kemendikbud pada beberapa lembaga program paket yang menyelenggarakan pendidikan agama.

3. Faktor pendukung atau potensi dalam penyelenggaraan pendidikan agama pada program paket adalah:a) animo masyarakat lebih menginginkan penyelenggaraan pendidikan program paket A, B dan C dilengkapi dengan pendidikan agama, b) munculnya ragam pola penyelenggaraan pendidikan agama pada lembaga program paket. Hasil penelitian menunjukkan bahwa penyelengggaraan pendidikan agama yang dikelola oleh swasta maupun pemerintah dilakukan dalam bentuk kurikulum, ekstrakurikuler dan terintegrasi (pendidikan agama dimasukkan dalam pelajaran umum), c) sebagian besar pennyelenggara pendidikan program paket sudah menggunakan kurikulum KTSP dalam menyelenggarakan pendidikan agama, d) banyaknya tutor Pendidikan Agama yang berstatus PNS yang kekurangan jam merupakan peluang untuk perekrutan tutor Pendidikan Agama pada penyelenggaran program paket.

\section{Rekomendasi}

1. Kementerian agama berkewajiban melakukan pembinaan dan pengembangan mutu pendidikan agama pada penyelenggaraan program paket. Adanya kewajiban tersebut Kementerian agama harus merespons permasalahan-permasalahan yang terkait dengan temuan survei ini, dengan membuat program-program yang mengarah ke solusi/pemecahan masalah.

2. Seluruh aparatur pemerintah di Kementerian Agama mulai dari struktur pusat sampai ke daerah merupakan unit pelayaan. Oleh karena itu, dalam rangka memaksimalkan penyelenggaraan pendidikan agama pada program paket, Kementerian Agama perlu melakukan pendataan berkaitan dengan data dan informasi, kendala, serta potensi yang bisa dijadikan kebijakan.

3. Perlu upaya pemerintah khususnya Kementerian Agama dan Dinas pendidikan setempat untuk melakukan kerja sama dalam penyelenggaraan pendidikan agama pada penyelenggaraan pendidikan program paket dalam rangka meningkakan mutu pendidikan agama pada program paket A, B, C khususnya dalam penyediaan buku/ modul pendiidkan agama, rekruitmen tutor pendiidkan agama, pemberian honori/insentif tutor pendidikan agama, pendidikan dan pelatihan tutor pendidikan agama, kegiatan MGMP pendidikan agama dan penyediaan sarana prasarana penyelenggaraan pendidikan agama. 


\section{SUMBER BACAAN}

Anam, Rosyidul (2012): Proses Pembelajaran Pendidikan Agama Islam Pada Warga Belajar Pendidikan Kesetaraan Paket A, Paket B, Paket C di PKBM Setia Mandiri, makalah, Jakarta.

Direktorat Jenderal Pendidikan NonFormal dan Informal (2007): Acuan Proses Pelaksanaan dan Pembelajaran Pendidikan Kesetaraan Program Paket A, B dan C, Departemen Pendidikan Nasional.

Direktorat Pendidikan Agama Islam (2011): Pedoman Pelaksanaan Pemenuhan Beban Kerja PAI pada Sekolah. Jakarta: Direktorat Jenderal Pendidikan Islam Kementerian Agama RI.

Djaali (2003): Bahan Ajar Metode Penelitian. Jakarta: PPs UNJ.

Fattah, Nanang (1997): Landasan Manajemen Pendidikan. Bandung: PT Remaja Rosda Karya.
Mulyadi (2012): Makalah Pembelajaran Pendidikan Agama Islam Pada Warga Belajar Pendidikan Kesetaraan Paket A, Paket B, Paket $C$ di PKBM Cengkarengi, Jakarta.

Peraturan Pemerintah Nomor 19 Tahun 2005 tentang Standar Nasional Pendidikan

Peraturan Mentri Pendidikan Nasional No 3 tahun 2008.

Postman, Neil (2001): Matinya pendidikan: Redefinisi nilai-nilai sekolah. Yogyakarta: Jendela.

Standar Kompetensi dan kompetensi dasar Pendidikan Kesetaraan Program Paket A dan Paket B. 2007. Kementerian Pendidikan dan Kebudayaan.

Undang-undang Nomor 20 Tahun 2003 Tentang Sistem Pendidikan Nasional. 